\title{
THE ROLE OF MACROBENTHIC COMMUNITIES AS AN INDICATOR FOR THE FERTILITY OF MANGROVE POND: CASE STUDY AT BLANAKAN, SUBANG, WEST JAVA
}

\author{
Joni Haryadi*\#, Hadiyanto*), and Mufti P. Patria***) \\ ") Center for Aquaculture Research and Development, Jakarta \\ *) Research Center for Oceanography, Indonesian Institute of Sciences \\ ${ }^{\left.*+u^{*}\right)}$ Faculty of Mathematic and Natural Science, University of Indonesia, Depok 16424
}

(Received 19 March 2014; Final revised 30 October 2014; Accepted 30 November 2014)

\begin{abstract}
Macrobenthic in mangrove ecosystems plays an important role as removal particles from the water column to the sediments. Ecology indexes of macrobenthic communities were used in this study as an indicator for the fertility of mangrove pond ecosystems. The study was carried out at mangrove pond in Blanakan, West Java. Data was collected from four sampling sites: opened pond (TB), sylvofishery pond (TS), sedimented pond (TT), and conservation pond (TP). Some ecological indexes such as Margalef's Index (R), Shannon-Wiener Index (H'), Pielou Evenness Index (E), and Simpson Dominance Index (D) were used to analyze macrobenthic communities. The results showed that infaunal macrobenthic communities were stable at TP with R: $1.91 \pm 0.42, H^{\prime}: 1.59 \pm 0.30, E: 0.74 \pm 0.14$, and $\mathrm{D}: 0.29 \pm 0.12$. They were unstable at TB with R: $1.63 \pm 0.80, H^{\prime}: 1.36 \pm 0.32, E: 0.74 \pm 0.06$, and $\mathrm{D}: 0.35 \pm 0.07$. The macrobenthic communities can be used as indicator for the fertility of mangrove pond in Blanakan, West Java.
\end{abstract}

KEYWORDS: macrobenthic, indicator, fertility, mangrove pond, Blanakan

\section{INTRODUCTION}

According to the size, benthic organisms are classified as microbenthic, meiobenthic, and macrobenthic. The microbenthic $(<32 \mu \mathrm{m})$ is composed of bacteria and protista. The meiobenthic $(32 \mu \mathrm{m}-1 \mathrm{~mm})$ is usually dominated by nematode. The macrobenthic $(>1 \mathrm{~mm})$ is composed of mollusk, polychaeta, echinoderm, crustacean, and other groups. Benthic organisms, based on feeding type, are also classified into two classes: suspension feeders, which filter their food directly from the water column, and deposit feeders, which depend on the physical deposition of food particles on the sediment surface, and the subsequent incorporation of the food particles into the sediment matrix (Herman et al., 1998).

Macrobenthic is an important component of mangrove ecosystems. They are both consumers and transporter in the energy flow and materials circulation of the system through activities such as ingesting food and digging (Aller \& Aller, 1998; Yi-jie et al., 2007). Between $5 \%$ and $25 \%$ of the annual primary production is consumed by macrobenthic respiration (Harding et al., 1986). Macrobenthic in mangrove ecosystems plays an important role as removal particles from the water column to the

\# Corresponding author. Center for Aquaculture Research and Development Jl. Ragunan 20, Pasar Minggu, Jakarta Selatan 12540, Indonesia. Phone: +62 217805052 E-mail: joniharyadi@yahoo.com 
sediments and as an important food resource for crustaceans, fish, birds, and human (Pirzan et al., 2006). Abundance and diversity of macrobenthic depend on several factors such as mangrove structures (Yi-jie et al., 2007), sediment characteristics (Kathesiran \& Bingham, 2001 ), temperature and salinity (Ferrari et al., 1994), as well as organic nitrogen (Tenore, 1988).

Macrobenthic has a unique habit to dig on mangrove sediment and to interact with its surrounding environment. The composition of macrobenthic depends on the sediment characteristics of the individual mangrove (Kathesiran \& Bingham, 2001). The structure of macrobenthic community can be used as potential biological or ecological index in order to recognize environmental changes in natural and artificial mangroves (Yi-jie et al., 2007). The diversity index commonly used to characterize species abundance and its relationship in communities. This index composes of two distinct components: the total number of species or species richness, and equitability or species evenness (Pirzan et al., 2006).

Since 1986-2008, Blanakan area is a potential and existing for fish and shrimp culture in the pond. Around the pond in Blanakan is surrounded by mangrove area. It might be the pond has very good fertility because it could be absorbed as nutrient by plankton from the compose of litter mangrove. Therefore the pond around mangrove was mentioned as mangrove pond. The utilization of mangrove forests in the Blanakan into various types of mangrove ponds creates ecological conditions that vary on each type of pond. Therefore, the studies of the ecology of the mangrove ponds are interesting topic to be learned.

The objective of this study was to investigate the role of macrobenthic communities as indicator for the fertility of mangrove pond at Blanakan, Subang, and West Java. This study is useful as a material consideration for the sustainable utilization of mangrove ecosystems.

\section{MATERIALS AND METHODS}

This study was carried out on April-June 2008 at mangrove pond in Blanakan, Subang, West Java (Figure 1). The sampling sites were based on percentage of mangrove cover such as opened pond (TB), sylvofishery pond (TS), sedimented pond (TT), and conservation pond (TP).

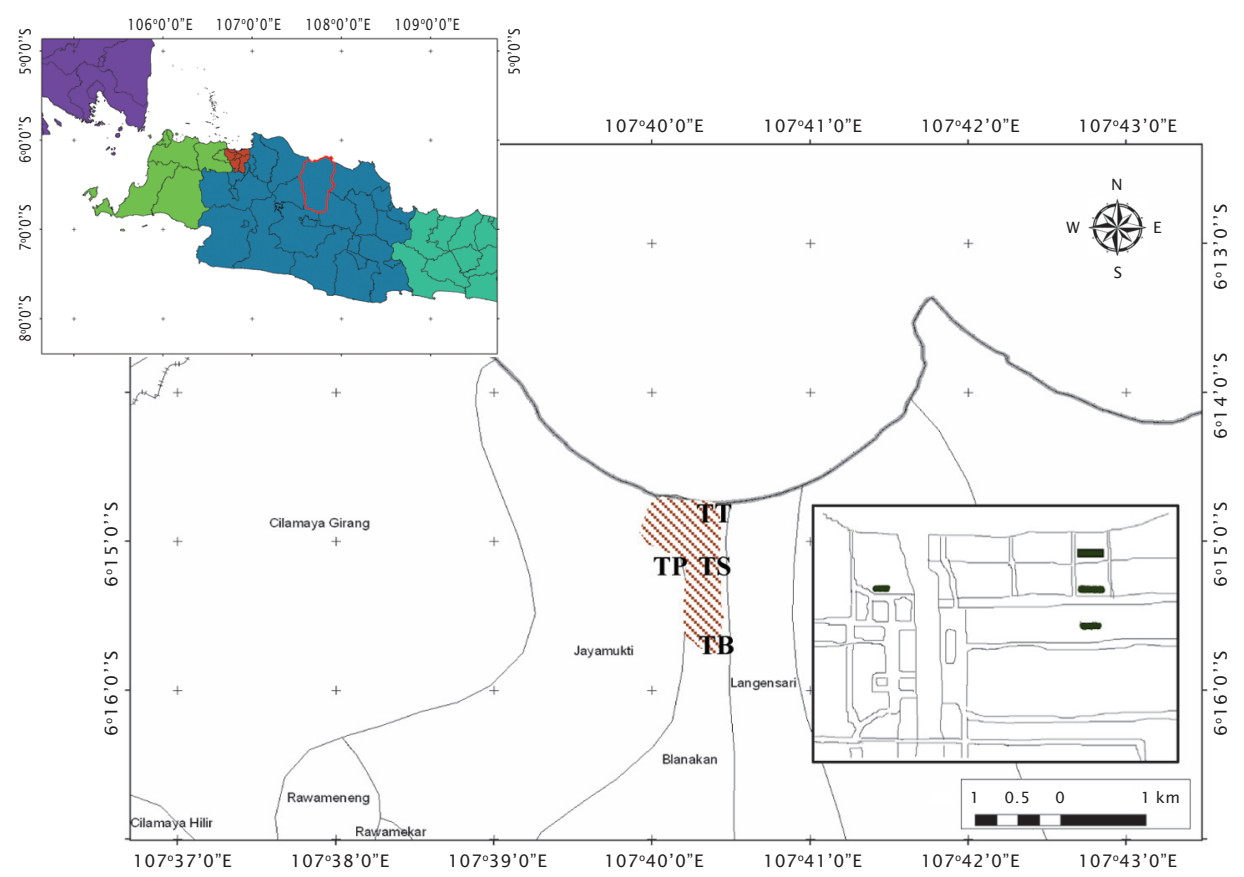

Figure 1. Map of study area at mangrove pond in Blanakan, West Java. TB: opened pond, TS: sylvofishery pond, TT: sedimented pond, and TP: conservation pond 
Sampling of macrobenthic was collected by taking the sediment using PVC core with 7 $\mathrm{cm}$ diameter and $15 \mathrm{~cm}$ height. The benthic samples were sieved using $1 \mathrm{~mm}$ meshsize in order to separate the benthic fauna from the substrate. The retained organisms were collected, preserved in $70 \%$ alcohol and identified based on Carpenter \& Niem (1998). Land cover, temperature, salinity, dissolved oxygen, and $\mathrm{pH}$ in water column were also measured at each sampling site. In addition, carbon, nitrogen, and phosphor contents in sediment were also analyzed. Data were analyzed at Soil Research Institute, Bogor.

The ecologycal indexes were used to examine the structure of macrobenthic communities. The indexes were used including richness species index (The Margalef's index/R), diversity index (The Shannon-Wiener index/ $\mathrm{H}^{\prime}$ ), evenness index (The Pielou Evenness index/E), and dominance index (The Simpson dominance index/D): The formula for each index as follow (Ludwig \& Reynolds 1988):

$$
\mathrm{R}=(\mathrm{S}-1) / \operatorname{Ln}(\mathrm{n})
$$

where:

$\mathrm{R}=$ Richness species index

$\mathrm{S}=$ Total number of species

$\mathrm{n}=$ Total number of individuals

$$
H^{\prime}=-\Sigma(p i x \operatorname{Ln} p i)
$$

where:

$\mathrm{H}^{\prime}=$ Diversity index

$\mathrm{Pi}=\mathrm{ni} / \mathrm{N}$

$\mathrm{ni}=$ Number individuals of the $i^{\text {th }}$ species

$\mathrm{N}=$ Total number of individuals

$$
\mathrm{E}=\mathrm{H}^{\prime} / \operatorname{Ln} \mathrm{S}
$$

where:

$\mathrm{E}=$ Evenness index

$H^{\prime}=$ Diversity index

$S=$ Total number of species

$$
\mathrm{D}=\Sigma(\mathrm{ni} / \mathrm{N})^{2}
$$

where:

$\mathrm{D}=$ Dominance index

$\mathrm{ni}=$ Number individuals of the $\mathrm{i}^{- \text {th }}$ species

$\mathrm{N}=$ Total number of individuals

\section{RESULTS AND DISCUSSIONS}

Base on characteristics of mangrove pond in Blanakan, West Java, the sampling sites were divided by percentage of mangrove covers at TB, TS, TT, and TP with $0 \%, 50 \%, 40 \%$, and $80 \%$, respectively. Water quality at the study site was fluctuated with temperature, salinity, DO and $\mathrm{pH}$ ranged of $29.85^{\circ} \mathrm{C}-30.84^{\circ} \mathrm{C} ; 8.63-26$ ppt; $2.73-7.93 \mathrm{mg} / \mathrm{L} ; 7.71-7.98$ respectively (Haryadi et al., 2013). Generally, condition of water quality at the study area were indicated suitable for brackishwater culture (Hassan, 1990; Joseph \& Gupta, 1996; Chanratchakool, 2003).

Sedimentary nutrient at mangrove pond in Blanakan is shown in Table 1. Based on the nitrogen content, Mintardjo et al. (1985) classified the fertility of sediment into four categories: (1) very low, nitrogen content less than $0.10 \%$; (2) low, nitrogen content between $0.11 \%$ $0.15 \%$; (3) moderate, nitrogen content between $0.16 \%-0.20 \%$; and (4) high, nitrogen content greater than $0.20 \%$. According to these categories, the fertility of sediments at TB, TS, and TP were indicated moderate, while at TT was indicated low. These condition might be related to the mangrove covers at each site. This mangrove covers play a potential role as trapper of nutrients (Lin \& Dushoff, 2004) and sediment (Kathiseran, 2003; Al-Nafisi et al., 2009).

Twenty five species of macrobenthic were indentified at mangrove pond in Blanakan, West Java. The composition of infaunal macrobenthic at mangrove pond is shown in Figure 2. Gastropod was found dominant with percentage coverage of about $38 \%-71 \%$ of the total number of species. The muddy or sandy sediments of

Table 1. Sedimentary nutrient at each sampling site $(\mathrm{N}=3)$ in Blanakan, Subang, West Java

\begin{tabular}{lcccc}
\hline Nut rient s & TB (\%) & TS (\%) & TT (\%) & TP (\%) \\
\hline Carbon & $2.48 \pm 0.78$ & $2.23 \pm 0.49$ & $1.70 \pm 0.41$ & $2.69 \pm 2.02$ \\
Nitrogen & $0.17 \pm 0.06$ & $0.18 \pm 0.04$ & $0.14 \pm 0.04$ & $0.17 \pm 0.03$ \\
Phosphor & $0.04 \pm 0.02$ & $0.03 \pm 0.01$ & $0.03 \pm 0.01$ & $0.03 \pm 0.01$ \\
\hline
\end{tabular}




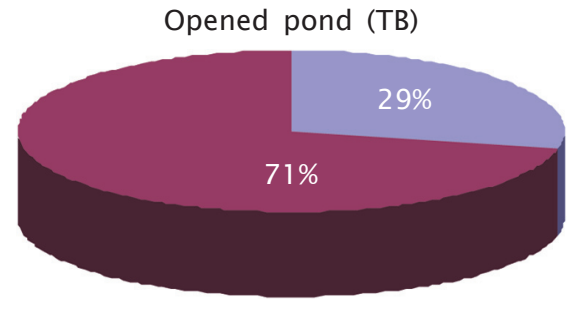

Sedimented pond (TT)

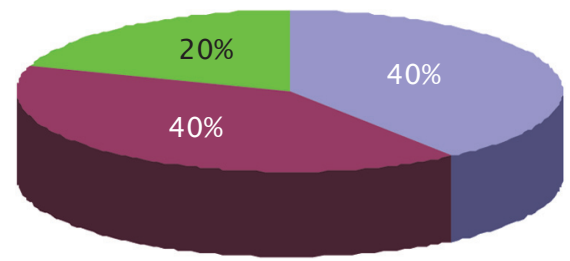

Sylvofishery pond (TS)

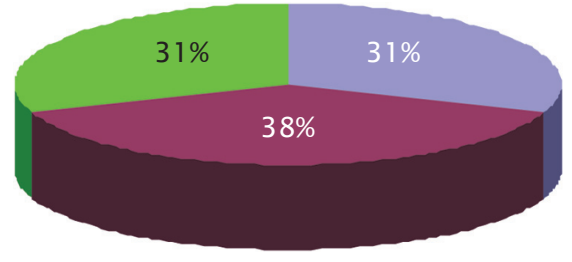

Conservation pond (TP)

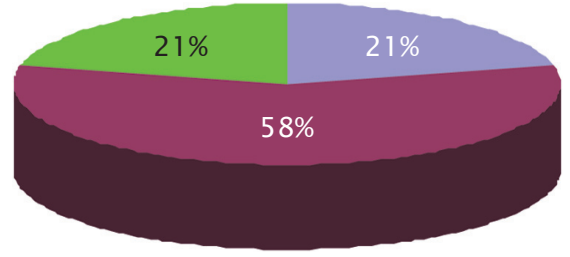

Polychaete

Castropod

Bivalve

Figure 2. The composition of infaunal macrobenthic at mangrove pond in Blanakan, Subang, West Java

the mangrove may be suitable habitat for macrobenthos fauna, i.e. gastropod (Hutchings \& Recher, 1981; Keshavarz et al., 2012). Gastropod could burried their body into sediments for searching food and avoid from predators. Deposit feeders, such as mollusca commonly inhabit in soft bottom of mangrove area (Kumar \& Khan, 2013). Similarly, softbottom macrobenthos in Indonesian mangrove ecosystem was dominated by mollusca (Nordhaus et al., 2009). Gastropod was also reported as dominant taxa at some mangrove areas in the world such as Sematan, Malaysia (Ashton et al., 2003), east coast of India (Raut et al., 2005) and Desa Deyao, Zhanjiang, Cina (Yi-jie et al., 2007).
The abundance of infaunal macrobenthic at Blanakan is shown in Figure 3. The abundance of infaunal macrobenthic at TB, TS, TT, and TP was accounted for 20,433 $\pm 10,051$ ind./ $\mathrm{m}^{3} ; 31,342 \pm 10,701$ ind./m $\mathrm{m}^{3} ; 17,143 \pm 9,057$ ind./ $\mathrm{m}^{3}$; and $40,346 \pm 16,306$ ind. $/ \mathrm{m}^{3}$, respectively. TP had the highest abundance of infaunal macrobenthic among other sampling sites. This condition might be related with the substrate at TP which is suitable for infaunal macrobenthic growth as well as the condition of mangrove covers. Substrate is an important factor for macrobenthic because of its role as home and source of organic matters (Sahri et al., 2000). In addition, mangrove at TP also play an

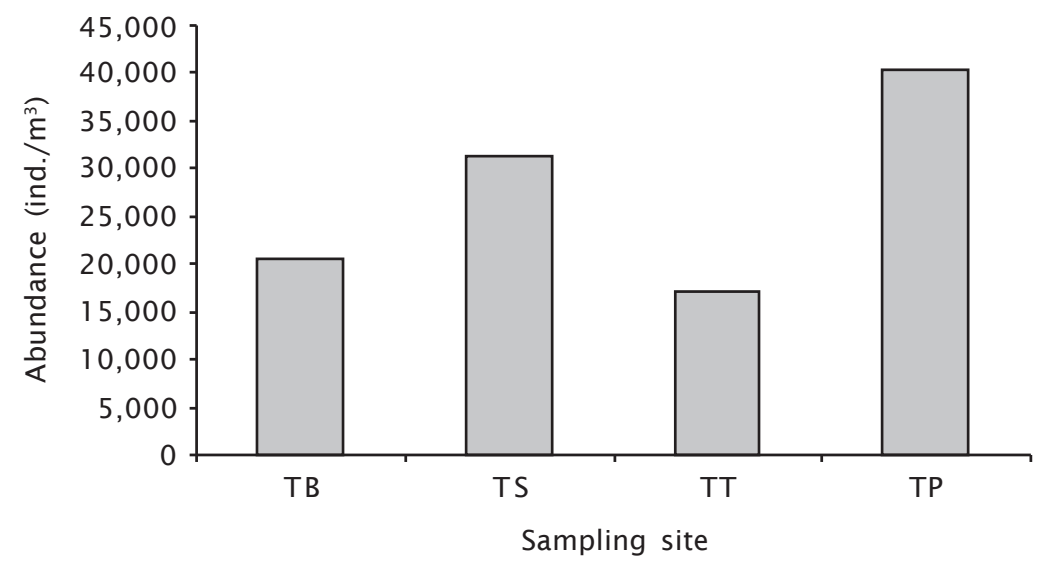

Figure 3. The abundance of infaunal macrobenthic $(\mathrm{N}=3)$ at mangrove pond in Blanakan, West Java 
important factor influencing the abundance of infaunal macrobenthic. Bosire et al. (2004) found that the abundance of crabs at mangrove area is higher than the area without mangrove. Many physico-chemical parameters affect macrobenthic communities in the mangrove area (Gowda et al., 2008), such as mangrove cover (Nordhaus et al., 2009; Thilagavathi et al., 2013) and sediment composition (Netto \& Galluci, 2003).

The structure of infaunal macrobenthic communities is shown in Figure 4. The Margalef's index $(R)$ of infaunal macrobenthic at $\mathrm{TB}, \mathrm{TS}, \mathrm{T}$, and TP were $1.63 \pm 0.80,1.91 \pm 0.42$, $1.61 \pm 0.53$, and $1.94 \pm 0.06$, respectively. The Shannon-Wiener index $\left(\mathrm{H}^{\prime}\right)$ of infaunal macrobenthic at TB, TS, TT, and TP were $1.36 \pm 0.32$, $1.59 \pm 0.30,1.54 \pm 0.24$, and $1.47 \pm 0.06$, respectively. According to Manguran (1988), the diversity ( $\left.H^{\prime}\right)$ at communities can be classified into three categories: (1) low, if H' less than 1, (2) moderate, if H' between 1 to 3, and (3) high, if $H^{\prime}$ greater than 3. Based on the categories by Manguran (1988), the diversity of infaunal macrobenthic at all sampling sites was classified as moderate. Simillar condition was reported at Kachchh, India (Saravanakumar et al., 2007) and mangrove Zhanjiang, Cina (Yi-jie et al., 2007).

The Pielou Evenness index (E) of infaunal macrobenthic at TB, TS, TT, and TP were $0.74 \pm$ $0.06,0.74 \pm 0.14,0.84 \pm 0.08$, and $0.66 \pm 0.02$, respectively. Suwangsa (2006) classified the uniformity at communities into five categories: (1) very high, if E greater than 0,81 , (2) higher, if $E$ between 0.61 to 0.8 , (3) high, if $E$ between
0.41 to 0.6 , (4) moderate, if $\mathrm{E}$ between 0.21 to 0.4 , and (5) low, if E less than 0.21 . According to these categories, the uniformity of infaunal macrobenthic at TT was classified as very high, while at TB, TS, and TP were classified as higher. The same condition was reported at some mangrove areas such as Zhanjiang, China (Yi-jie et al., 2007) and mangrove Kachchh, India (Saravanakumar et al., 2007).

The Simpson Dominance index (D) of infaunal macrobenthic at TB, TS, TT, and TP was $0.35 \pm 0.07,0.29 \pm 0.12,0.26 \pm 0.07$, and $0.32 \pm$ 0.02 , respectively. These results showed that no dominant species was found in the study area. This condition indicated that the structures of infaunal macrobenthic community were indicated stable and also suitable for infaunal macrobenthic.

Table 2 shows the resume of the structure of infaunal macrobenthic communities at mangrove pond in Blanakan, West Java. According to Ludwig \& Reynolds (1988), the communities were indicated stable if $R, H^{\prime}$, and $E$ indexes were high, and $D$ index was low. Based on the Table 2, infaunal macrobenthic communities had the most stable at TS, while the most labile at TB. The stability of infaunal macrobenthic at TS related with the condition of mangrove forests at its location. On the other hand, the degradation of mangrove forests at TB caused the dominance of infaunal macrobenthic at its location to be very high. The main factors influencing the number of species, diversity, and dominance changes were the degradation of natural habitat (Ellison, 2008) and pollution (Bigot et al., 2006).

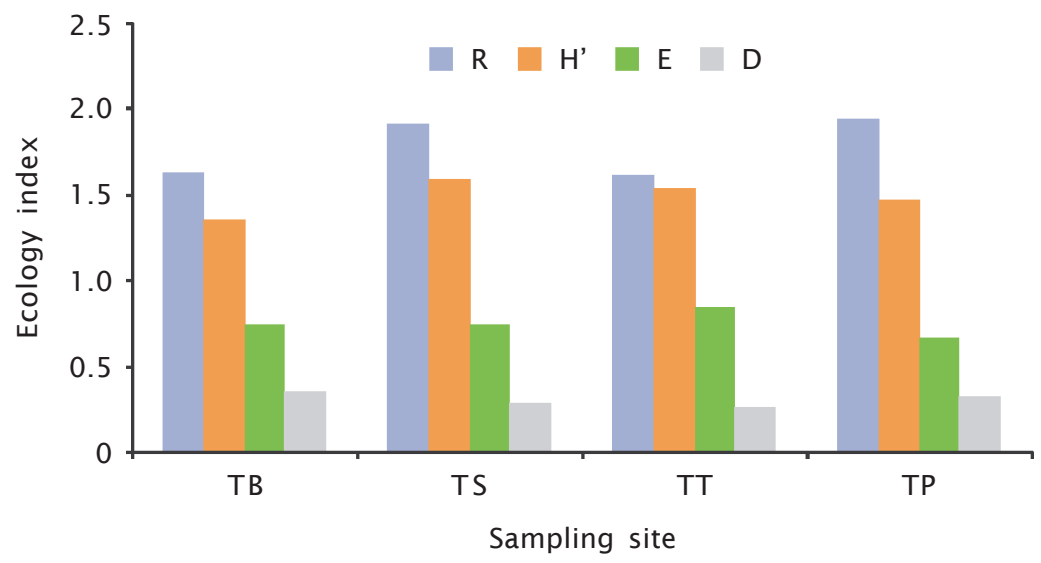

Figure 4. The structure of infaunal macrobenthic communities $(N=3)$ at mangrove pond in Blanakan, West Java 
Table 2. The resume of the structure of infaunal macrobenthic communities at mangrove pond in Blanakan, West Java

\begin{tabular}{cc}
\hline Parameter & Trend \\
\hline$R$ & $\mathrm{TT}<\mathrm{TB}<\mathrm{TS}<\mathrm{TP}$ \\
$H^{\prime}$ & $\mathrm{TB}<\mathrm{TP}<\mathrm{TT}<\mathrm{TS}$ \\
$\mathrm{E}$ & $\mathrm{TP}<\mathrm{TB}<\mathrm{TS}<\mathrm{TT}$ \\
$\mathrm{D}$ & $\mathrm{TT}<\mathrm{TS}<\mathrm{TP}<\mathrm{TB}$ \\
\hline
\end{tabular}

At the study area, the dominance of infaunal macrobenthic was highest at TP, whereas the mangrove cover at TP was the highest than other sampling sites. The old mangroves at TP were unsuitable for infaunal macrobenthic. The old mangrove caused lower habitat quality because of accumulation of sediments so that the concentration of dissolved oxygen and water temperature at this location decreased gradually. These were causing reduction of decomposition rate and productivity. The high concentration of tannins resulted by old mangrove showed negative effect on the aquatic organism communities because of it's toxic containt (Morrisey et al., 2007).

The studies on the macrobenthic as indicator for the fertility of pond were also demonstrated by some researchers (Raut et al., 2005; Pirzan et al., 2006; Yi-jie et al., 2007). Macrobenthos is the best bio-indicator for determining sediment quality because of three main reasons: sedentary, low natural variability, and responsive to organic enrichment (Mucha et al., 2003). Furthermore, macrobenthos show a perceptible respond to organic enrichment through some actions: (1) a decrease in spe- cies richness, (2) an increase in abundance of opportunistic species, and (3) a shift in size classes from large to small-sized species (Chintiroglou et al., 2006).

The relationship between sedimentary carbon and nitrogen with abundance and diversity of infaunal macrobenthic at mangrove pond in Blanakan, West Java is shown in Figure 5. The abundance of infaunal macrobenthic increase with increasing sedimentary carbon and nitrogen. These can be understood because sedimentary carbon and nitrogen were a source of food for benthic animals, particularly mollusca (Herman et al., 1998; MacDonald et al., 2010).

The sedimentary organic matter together with sediment textures influence the diversity of macrobenthic at some mangrove areas (Yijie et al., 2007; Sivadas et al., 2013). Increasing sedimentary nutrients could increase the diversity of macrobenthic at Mamuju pond (Pirzan \& Gunarto, 2004), Tampinna lagoon, East Luwu (Pirzan et al., 2006). However, increasing sedimentary carbon and nitrogen could decrease the diversity of infaunal macrobenthic at mangrove pond in Blanakan. This is causing the requirement of carbon and nitrogen at each infaunal macrobenthic was different. Infaunal macrobenthic species may be very responsive to sedimentary carbon and nitrogen so their growth are very fast and dominate to the other species. The same case was reported by Lestari et al. (2005) that increasing $\mathrm{BOD}_{5}$ was caused organic matter pollution could decrease the diversity of macrobenthic.

Organic matters and community structures were an indicator for the fertility of ecosystems. Results of this study showed that the fertility at TS was moderate, while at TT was
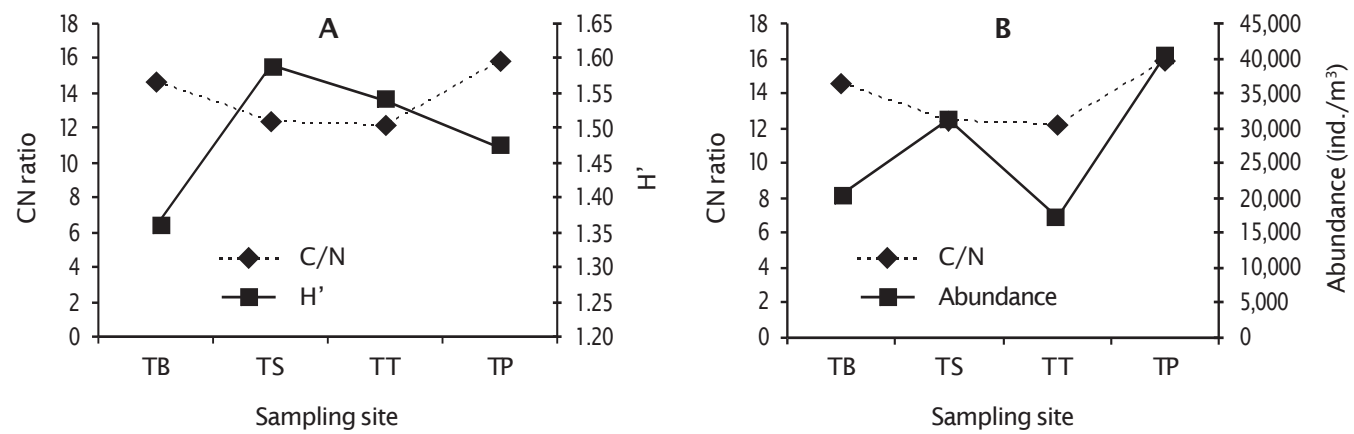

Figure 5. The relationship of sedimentary $\mathrm{C} / \mathrm{N}$ with abundance $(\mathrm{A})$ and diversity (B) of infaunal macrobenthic at mangrove pond in Blanakan, West Java 
low. On the other hand, the community of infaunal macrobenthic was the most stable at TS, while the most labile at TB. These showed that locations with high fertility tend to have more stable community. Therefore, the ecology index of infaunal macrobenthic communities can be used as an indicator for the fertility of mangrove pond at mangrove pond in Blanakan but this study still requires some additional data and information as well as further studies to obtain a detail role of infauna macrobenthic for determining the level of stability and fertility of mangrove pond in Blanakan.

\section{CONCLUSION}

The structure of infaunal macrobenthic communities can be used as an indicator for the fertility of Blanakan pond. In this study, the community of infaunal macrobenthic was the most stable at sylvofishery pond (TS), while the most labile at opened pond (TB). Finding from this study could be used as a material consideration for the sustainable utilization of mangrove ecosystems.

\section{REFERENCES}

Aller, R.C., \& Aller, J.Y. (1998). The effect of biogenic irrigation intensity and solute exchange on diagenetic reaction rate in marine sediment. Journal of Marine Research, 56, 905-936.

Al-Nafisi, R.S., Al-Ghadban, A., Gharib, I., \& Bhat, N.R. (2009). Positive impacts of mangrove plantations on Kuwait's coastal environment. European Journal of Scientific Research, 26(4), 510-521.

Ashton E.C., Macintosh, D.J., \& Hogarth. P.J. (2003). A baseline study of the diversity and community ecology of crab and molluscan macrofauna in the Sematan mangrove forest, Serawak, Malaysia. Journal of Trophical Ecology, 19(2), 127-142.

Carpenter, K.E., \& Niem, V.H. (1998). Species identification guide for fishery purposes: The living marine resources of the Western Central Pacific. FFA, FAO and NORAD. Roma.

Chanratchakool, P. (2003). Problems in Penaeus monodon culture in low salinity areas. Aquaculture Asia, 8(1), 54-56.

Chintiroglou, C., Antoniadou, C., \& Krestenitis, Y. (2006). Can polychaetes be used as a surrogate group in assessing ecological quality of soft substratum communities ( $\mathrm{Ne}$ Thermaikos Gulf)? Fresenius Environmental
Bulletin, 15(2), $1199-1207$.

Ellison, A.M. (2008). Managing mangrove with benthic biodiversity in mind: moving beyond roving banditry. Journal of Sea Research, 59, 2-15.

Ferrari, J.D., Fauchald, K., \& Kensley, B. (1994). Physiological responses to fluctuation in temperature or salinity in invertebrates: adaptation of Alpheus viridari (Decapoda, Crustacea), Terebellides parva (Polychaeta) and Golfinigia cylindrata (Sipunculida) to the mangrove habitats. Marine Biology, 120(3), 397-406.

Fitriana, Y.R. (2006). Keanekaragaman dan kemelimpahan makrozoobenthos di hutan mangrove hasil rehabilitasi taman hutan raya Ngurah Rai, Bali. Biodiversitas, 7(1), 6772.

Gowda, G., Rajesh, K.M., \& Mridula, R.M. (2008). Abundance and vertical distribution of macrobenthos in a mangrove-fringed brackish water pond in Mangalore, India. The Ecoscan, 2(2), 181-186.

Handayani, Y.D. (2004). Analisis ekonomi pemanfaatan hutan mangrove menjadi tambak tumpangsari (Studi kasus: Desa Muara Kecamatan Blanakan Kabupaten Subang). Tesis. Sekolah Pascasarjana. Institut Pertanian Bogor. Bogor, $172 \mathrm{hlm}$.

Harding, L.W., Meeson, B.W., \& Fisher, T.R. (1986). Decay time of organic carbon in sedimented detritus in a macrotidal estuary. Marine Ecology Progress Series, 56, 217-279.

Hassan, R. (1990). Garis panduan mutu air untuk ternakan ikan dan udang laut. Risalah Perikanan. Jabatan Perikanan. Malaysia, $43 \mathrm{hlm}$.

Heip, C.H.R., Goosen, N.K., Herman, P.M.J., Kromkamp, J., Middelburg, J.J., \& Soetaert, K. (1995). Production and consumption of biological particles in temperate tidal estuaries. Oceanography and Marine Biology Annual Review, 33, 1-150.

Herman, P.M.J., Middleburg, J.J., Koppel, J.V.D., \& Heip, C.H.R. (1998). Ecology of estuarine macrobenthos. Ecological Research, 29, 195-240.

Hutchings, P.A., \&. Recher, H.F. (1981). The fauna of Australian mangroves. Linnealogy Society of New South Wales, 106(1), 84-109.

Haryadi, J., Basukiardi, A., \& Muhadiono. (2013). The study on mangrove litter as a source of nutrient for Blanakan Pond, Subang. Indonesia aquaculture journal, 8(1), 55-64.

Joseph, K.O., \& Gupta, B.P. (1996). Shrimp cul- 
ture: water quality management. Central Institute of Brackishwater Aquaculture (Indian Council of Agriculture Research). Madras, $4 \mathrm{pp}$.

Kathesiran, K., \& Bingham, B.L. (2001). Biology of mangroves and mangrove ecosystems. Marine Biology, 40, 81-251.

Kathiseran, K. (2003). How do mangrove forests induce sedimentation? Rev. Biol. Trop., 51(2), 355-360.

Keshavarz, M., Kamrani, E., \& Dabbagh, A. (2012). A description of higher macrobenthic infaunal taxa of mangrove mud flats at Khamir Port, Iran. Annals of Biological Research, 3(2), 1029-1043.

Kumar, P.S., \& Khan, A.B. (2013). The distribution and diversity of benthic macroinvertebrate fauna in Pondicherry mangroves, India. Aquatic Biosystems, 9(15), 1-18.

Lestari, S., Dewi, R.S., \& Aziz, S. (2005). Kajian penggunaan struktur komunitas makrobenthos dan indeks biotik sebagai indikator pencemaran organik. In Yuwono, E., Sukardi, P., Hilmi, E., Susilo, U., Simanjuntak, S.B.I., Haryadi, B., \& Rachmawati, F.N. Prosiding Seminar Nasional Biologi dan Akuakultur Berkelanjutan: Pengembangan Sains dan Teknologi untuk Pemanfaatan Sumberdaya Perairan Tropis Secara Berkelanjutan. Fakultas Biologi dan Program Sarjana Perikanan dan Kelautan, Universitas Jenderal Soedirman. Purwokerto, hlm. 425-431.

Lin, B.B., \& Dushoff, J.D. (2004). Mangrove filtration of anthropogenic nutrients in the Rio Coco Solo, Panama. Management of Environmental Quality, 15(2), 131-142.

Ludwig, J.A., \& Reynolds, J.F. (1988). Statistical ecology: a primer on methods and computing. John Wiley \& Sons. New York, Chichester, Brisbane, Toronto and Singapore, $338 \mathrm{pp}$.

MacDonald, T.A., Burd, B.J., MacDonald, V.I., \& van Roodselaar, A. (2010). Taxonomic and feeding guild classification for the marine benthic macroinvertebrates of the strait of Georgia, British Columbia. Ocean Science Divion, Fisheries and Oceana Canada. Sidney, $63 \mathrm{pp}$.

Mintardjo, K., Sunaryanto, A., Utaminingsih, \& Hermiyaningsih. (1985). Persyaratan tanah dan air. In Anonim. Pedoman Budidaya Tambak. Ditjen Perikanan, Departemen Pertanian. Jakarta.

Morrisey, D.J., Beard, C., Morrison, M., Craggs, R., \& Lowe, M. (2007). The New Zealand mangrove: review of the current state of knowledge. Auckland Regional Council Technical Publication. Auckland, 162 pp.

Mucha, A., Vasconcelos, T., \& Bordalo, A. (2003). Macrobenthic community in the Douro estuary: relations with trace metals and natural sediment characteristics. Environ. Poll., 121, 169-180.

Netto, S.A., \& Galluci, F. (2003). Meiofauna and macrofauna communities in a mangrove from the Island of Santa Catarina, South Brazil. Hydrobiologia, 505, 159-170.

Nordhaus, I., Hadipudjana, F.A., Janssen, R., \& Pamungkas, J. (2009). Spatio-temporal variation of macrobenthic communities in the mangrove-fringed Segara Anakan lagoon, Indonesia, affected by anthropogenic activities. Reg. Environ. Change, 9, 291-313.

Nur, S.H. (2002). Pemanfaatan ekosistem hutan mangrove secara lestari untuk tambak tumpangsari di Kabupaten Indramayu, Jawa Barat. Disertasi. Program Pascasarjana. Institut Pertanian Bogor. Bogor, 249 hlm.

Pantjara, B., Aliman, Mangampa, M., Pongsapan, D.S., \& Utojo. (2006). Kesesuaian dan pengelolaan lahan budi daya tambak di Kabupaten Kotabaru, Kalimantan Selatan. Jurnal Riset Akuakultur, 1(1), 131-141.

Perhutani. (1988). Pedoman Pelaksanaan Program Perhutanan Sosial. Perum Perhutani. Jakarta.

Pirzan, A.M., \& Gunarto. (2004). Keragaman makrobenthos dalam hubungannya dengan substrat di kawasan tambak, Kabupaten Mamuju. Jurnal Penelitian Perikanan Indonesia, 10(1), 1-11.

Pirzan, A.M., Burhanuddin, Gunarto, \& Utojo. (2006). Dampak pembukaan lahan mangrove terhadap diversitas makrozoobenthos di perairan Delta Tampinna, Luwu Timur. In Ahmad, T., Syah, R., Mustafa, A., \& Priono, B. (2006). Kajian Keragaan dan Pemanfaatan Lingkungan Perikanan Budidaya. Pusat Riset Perikanan Budidaya. Jakarta, hlm. 109-119.

Sahri, A., Budiman, W., \& Andriyani, A. (2000). Keragaman makrobenthos pada berbagai substrat buatan di Sungai Ciglagah, Cilacap. Biosfera, 15, 19-25.

Saravanakumar, A., Serebiah, J.S., Thivakaran, G.A., \& Rajkumar, M. (2007). Benthic macrofaunal assemblage in the arid zone mangroves of gulf of Kachchh-Gujarat. Journal of Ocean University of China, 6(3), 303-309. 
Sivadas, S.K., Ingole, B.S., \& Fernandes, C.E.G. (2013). Environmental gradient favours functionally diverse macrobenthic community in a placer rich tropical bay. Hindawi, p. 1-12.

Suwangsa, I.H. (2006). Keanekaragaman plankton di perairan Danau Beratan, Bali. Skripsi. Program Studi Biologi, Jurusan Matematika dan Ilmu Pengetahuan Alam, Fakultas Sains dan Teknologi, UIN Syarif Hidayatullah. Jakarta.

Tenore, K.R. (1988). Nitrogen in benthic food chains. In Blackburn, T.H., \& Sorensen, J. (Eds.) Nitrogen Cycling in Coastal Marine Environments. John Wiley. New York, p. 191-206.

Thilagavathi, B., Varadharajan, D., Babu, A., Manoharan, J., Vijayalashmi, S., \& Balasubramanian, T. (2013). Distribution and diversity of macrobenthos in different mangrove ecosystems of Tamil Nadu Coast, India. J. Aquac. Res. Development, 4(6), 1-12.
Tresna, E. (2002). Kondisi hutan mangrove dan komunitas ikan di perairan mangrove Teluk Jakarta. Tesis. Program Studi Biologi, Program Pascasarjana, Fakultas Matematika dan Ilmu Pengetahuan Alam, Universitas Indonesia. Depok, $91 \mathrm{hlm}$.

Yani, E. (2005). Perkembangan Rhizophora mucronata Lam. dan Bruguiera gymnorhiza (L.) Lam di hutan mangove Cikiperan Cilacap. In Yuwono, E., Sukardi, P., Hilmi, E., Susilo, U., Simanjuntak, S.B.I., Haryadi, B., \& Rachmawati, F.N. (2005). Prosiding Seminar Nasional Biologi dan Akuakultur Berkelanjutan: Pengembangan Sains dan Teknologi untuk Pemanfaatan Sumberdaya Perairan Tropis Secara Berkelanjutan. Fakultas Biologi dan Program Sarjana Perikanan dan Kelautan, Universitas Jenderal Soedirman. Purwokerto, hlm. 38-40.

Yi-jie, T., Shi-xiao, Y., \& Yan-yong, W. (2007). A comparison of macrofauna communities in different mangroves assemblages. Zoological Research, 28(3), 255-264. 